\title{
Spatio-temporal variation of the zooplankton community in a tropical caldera lake with intensive aquaculture (Lake Taal, Philippines)
}

\author{
Rey Donne S. Papa • Macrina T. Zafaralla • \\ Reiner Eckmann
}

\begin{abstract}
Zooplankton were collected from Lake Taal between January and December 2008 in order to test for differences in species composition and abundance between a lake basin with intensive fish cage (FC) aquaculture and an open water area without FCs. Most species showed similar patterns of occurrence in both basins while having differences in abundance. Several rotifer species were more abundant in FC sites most of the year, while for microcrustaceans higher abundances in FC sites only happened during the first 2 months. Their distribution is attributed to the presence of higher nutrient levels in FC sites as well as wind-induced basin-wide water movements during the different monsoon seasons which disperse plankton and nutrients from FC sites to other parts of the lake. Zooplanktonic indicators,
\end{abstract}

Handling editor: Karl E. Havens

R. D. S. Papa (ه)

Department of Biological Sciences, Graduate School and Research Center for the Natural Sciences,

University of Santo Tomas, Manila, Philippines

e mail: rspapa@mnl.ust.edu.ph; reypaps@yahoo.com

M. T. Zafaralla

Institute of Biological Sciences, University

of the Philippines Los Banos College, Laguna, Philippines

R. Eckmann

Limnological Institute, University of Konstanz,

Constance, Germany such as the Brachionus Trichocerca quotient $\left(Q_{\mathrm{B} / \mathrm{T}}\right)$ and the ratio of calanoids to cladocerans and cyclopoids, clearly demonstrate the eutrophic state of the lake. A comparison with previous studies suggests that the lake was already eutrophic prior to the introduction of aquaculture in the 1970s. The trophic conditions in Lake Taal may be attributed to the lakes' tropical and volcanic nature, with productivity further enhanced by increased nutrient input from aquaculture.

Keywords Atelomixis - Sardinella tawilis . Monsoon seasons - Brachionus Trichocerca quotient

\section{Introduction}

The limnological features of tropical lakes are strongly affected by rain and wind during the monsoon seasons, both of which influence mixing and stratification. Strong winds and intense rainfall following episodes of hot weather can lead to the formation of multiple thermoclines, while heavy precipitation also promotes nutrient runoff from the watershed. Together with high average temperatures and intense solar radiation, these factors support high productivity in tropical lakes (Talling \& Lemoalle, 1998).

Volcanic lakes are a product of previous or persisting volcanic activity. The rocks and sediments in such lakes are natural sources of phosphorous, thus 
providing nutrients to boost phytoplankton growth. Active volcano lakes may have thermal vents that serve as benthic heat sources and thereby enhance the mixing of layers (Golterman, 1973; Talling \& Lemoalle, 1998; Amarasinghe et al., 2008). About $10 \%$ of the total number of lakes worldwide occur in the tropics and of these, $10 \%$ are of volcanic origin (Lewis Jr., 1996). The unique combination of characteristics found in tropical volcanic lakes makes them particularly prone to eutrophication (Lewis Jr., 2000; Amarasinghe et al., 2008). Lake Taal, the site of this study, is an active tropical volcanic lake located in Luzon, the largest island of the Philippine archipelago. The lake occupies the remains of a collapsed caldera and has a volcanic island at its center. The island separates the lake into two basins a shallower northern zone in which fish cage (FC) culture is practiced intensively and a deeper southern area, from which aquaculture cages are absent.

Aquaculture, the branch of agriculture concerned with the farming of aquatic life, has increased at an average annual rate of $9.2 \%$ since 1970 , compared with only $1.4 \%$ for capture fisheries and $2.8 \%$ for terrestrial farmed meat production (www.FAO.org). This impressive growth rate is closely linked with the ever increasing world population and the concomitant rise in demand for food. However, mismanagement and a lack of proper scientific guidance have often meant the ecosystem health has been sacrificed in attempts to maximize profit and yield. The excessive use of commercial feeds increases nutrient input into aquatic ecosystems (Borges et al., 2010), enhancing phytoplankton growth, decreasing water transparency, and increasing microbial activity in the sediments. In Lake Taal, aquaculture in net cages started in 1975 and by the year 2000 was contributing $15,268 \mathrm{mt}$ or $52 \%$ of the country's total annual FC culture production (Vista et al., 2006). At present, Nile tilapia (Oreochromis spp.) and milkfish (Chanos chanos) are the most commonly reared fish (Aypa et al., 2008) in the lake. In 2006, the Lake Taal milkfish and tilapia were supplied with an average of 144 and $60.5 \mathrm{~kg}$ of feed per day, respectively (White et al., 2007). Past under-regulation of stocking densities and feed inputs into Lake Taal has led to a decline in water quality (Mamaril Sr., 2001) which has threatened open water (OW) fisheries and depreciated the esthetic value of the lake. In response, a new Taal Volcano Protected Landscape Management Plan has been organized in order to monitor the lake and its watershed (Tvpl-Pamb, 2009).

Zooplankton community structure, population dynamics, and production are strongly influenced by lake productivity (Sousa et al., 2008; Zhou et al., 2009). The response of zooplankton to changes in nutrient content is a useful means of monitoring the anthropogenic eutrophication of lakes. We employed this approach to assess the current state of Lake Taal and to compare it with previous data on the lake's trophic condition.

We hypothesized that aquaculture was the main cause of eutrophication in Lake Taal, and that its effects would be manifest in the structure of the zooplankton community. We further hypothesized that spatial patterns of zooplankton abundance and composition would reflect patterns of nutrient input, i.e., we expected to find differences between culture areas and $\mathrm{FC}$ free $\mathrm{OW}$.

\section{Materials and methods}

Study area

Lake Taal $\left(13^{\circ} 55^{\prime} 14^{\circ} 05^{\prime} \mathrm{N}, 120^{\circ} 55^{\prime} 121^{\circ} 105^{\prime} \mathrm{E}\right)$ is the third largest lake in the Philippines. It is a caldera lake with a surface area of $268 \mathrm{~km}^{2}$ with mean and maximum depths of 90.4 and $198 \mathrm{~m}$, respectively. Lake volume is $21,426 \times 10^{6} \mathrm{~m}^{3}$ with a $682.8-\mathrm{km}^{2}$ catchment area and drains via the Pansipit River to Balayan Bay in the southwest (Papa et al., 2008; Perez et al., 2008). It is home to the worlds' lowest active volcano (Taal volcano island), which has erupted 33 times since 1572 (Zlotnicki et al., 2009). Taal Volcano Island partially separates the north (max. depth $100 \mathrm{~m}$ ) and south (max. depth $198 \mathrm{~m}$ ) basins of the lake (Ramos, 2002; Perez et al., 2008). Lake water is neutral to slightly alkaline $(7.28 .9 \mathrm{pH})$ with high conductivity $(1,6001,700 \mu \mathrm{S} / \mathrm{cm})$ (Perez et al., 2008).

\section{Sampling}

A total of six sites representing OW (south basin) and FC areas (north basin) were sampled monthly from January to December 2008 (Fig. 1). Temperature, dissolved oxygen (DO), and transparency were 


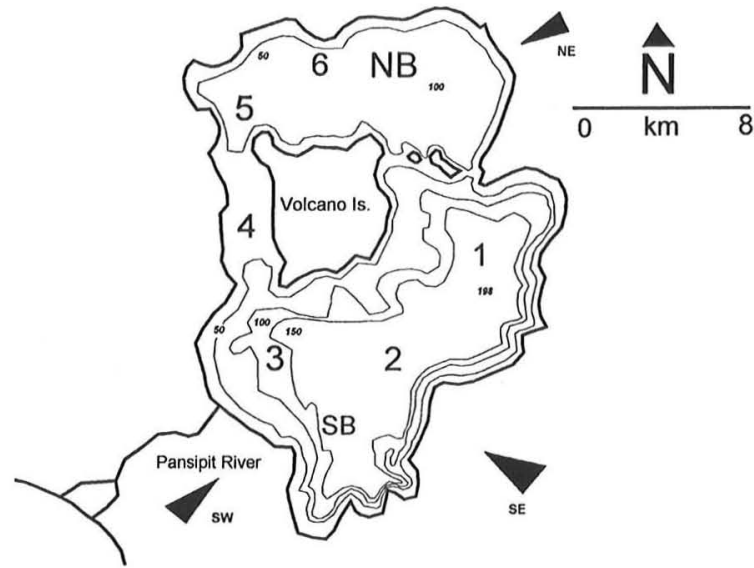

Fig. 1 Map showing the six sampling sites in the north (NB) and south (SB) basins of Lake Taal. Arrows indicate wind direction during the northeast (NE), southeast (SE), and southwest (SW) monsoons

measured using a Radioshack infrared thermometer, the Winkler iodometric method, and a Secchi disc, respectively. Plankton samples were obtained with two replicate vertical tows per site from $40 \mathrm{~m}$ to the surface using a conical $80-\mu \mathrm{m}$ mesh plankton net $($ diameter $=30 \mathrm{~cm})$ and fixed in $5 \%$ formalin.

Mean daily total rainfall, prevailing wind direction and details of tropical storms, depressions, and typhoons during the 2 weeks prior to each sampling were obtained from the government-run weather station. The number of FCs was obtained from the Provincial Government Environment and Natural Resources Office (PGENRO) of Batangas Province.

Specimen processing

Zooplankton identification was performed to species level for rotifers and cladocerans, while copepods were grouped into adult male or female cyclopoids or calanoids, and copepodite or nauplius stages according to Fernando (2002), Mamaril (1986), Mamaril \& Fernando (1978), Dussart \& Defaye (2001) and Petersen (2007). The number of egg-bearing females was also tallied. Density was determined by counting zooplankton in three 1-ml Sedgewick-Rafter subsamples per replicate (Wetzel \& Likens, 1991). Individual lengths were measured to the nearest $0.025 \mathrm{~mm}$ (Amarasinghe et al., 2008). Total biomass (in $\mu \mathrm{g} / \mathrm{l}$ ) was determined for each taxon using length weight regressions from Lewis (1979), Urabe (1992),
Unger \& Lewis (1991), and Amarasinghe et al. (2008).

Data analysis

Data were analyzed using PAST Software Version 1.81. Normal distribution was tested using the Shapiro Wilk test. Differences in spatio-temporal abundance, biomass, and physico-chemical variables were determined after values were $\log (x+1)$ transformed and compared across sampling periods using Kruskal Wallis ANOVA with a Bonferroni corrected pairwise Mann Whitney as a post hoc test. Principal component analysis was used to ordinate 72 sample units and 4 factorial axes, which were grouped according to monsoon season. The relationship of zooplankton biomass to physico-chemical data and FC number was analyzed using canonical correspondence analysis (CCA) with Type II Scaling, while Cluster Analyses with Bray Curtis similarity matrices were used to determine similarities in taxon occurrence. The Brachionus Trichocerca quotient $\left(Q_{\mathrm{B} / \mathrm{T}}\right)$ (Sládecek, 1983) and the calanoid to cladocera + cyclopoid ratio were computed to quantify zooplankton community characteristics in relation to trophic status.

\section{Results}

Physico-chemical and meteorological variables

Secchi disc transparency (SDT) ranged between 1.5 and $6.9 \mathrm{~m}$ with the highest values recorded in OW sites in January and February and the lowest values seen in March and May in the FC sites (Fig. 2). SDT in OW sites was higher than in FC sites for the first 5 months of the sampling year. The succeeding months saw similar SDT for OW and FC sites, except July and November, when OW sites had higher values than FC sites. Surface water temperatures were similar for both basins, ranging between 25.9 and $31.3^{\circ} \mathrm{C}$. The lowest temperatures were observed in January and February, while highest temperatures were recorded in July. Surface DO values ranged between 6.8 and $12.3 \mathrm{mg} / \mathrm{l}$, and though similar for both basins were generally higher in OW sites except in the months of May, June, September, and November. 
Fig. 2 Secchi disc transparency, surface water temperature, and surface dissolved oxygen (DO) of Lake Taal in 2008.

Kruskal Wallis ANOVA $P$ values for SDT: 0.002 , for Temp: 0.79 , for DO: 0.42 . Significance was accepted at $P<0.016$

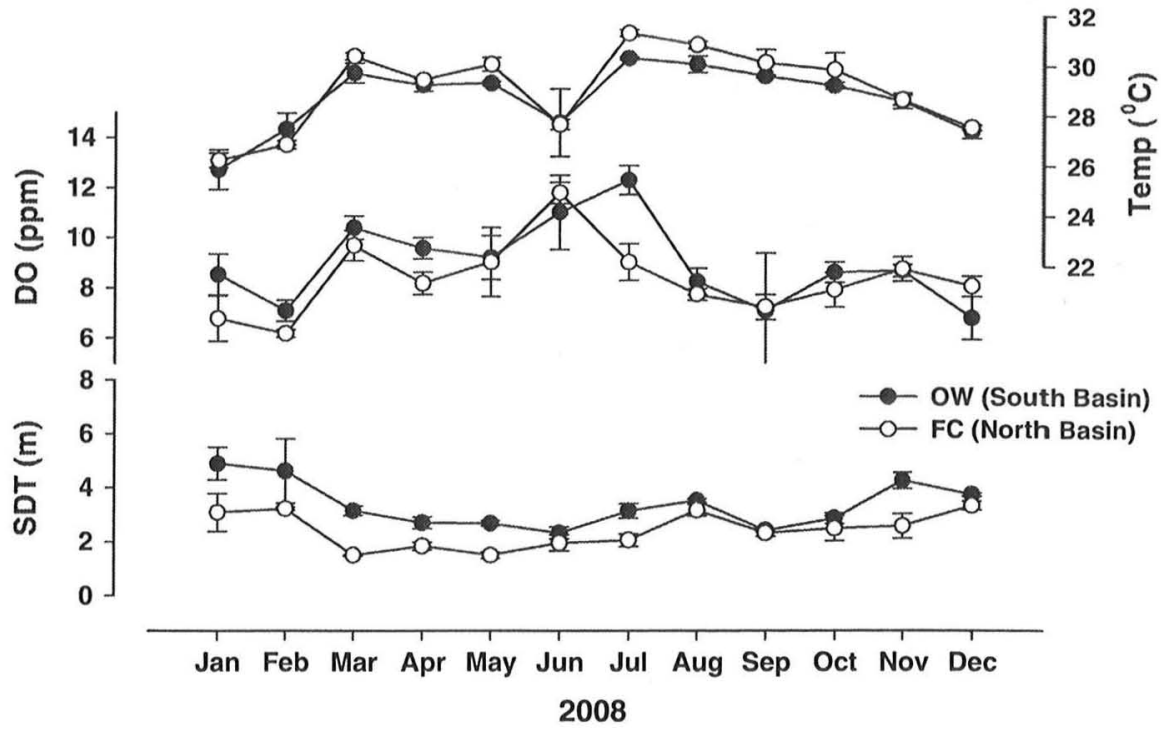

Rotifers

Seven typhoons/tropical storms/tropical depressions occurred within the 2-week periods prior to each sampling. May saw three typhoons, while June, July, August and September had one each. Total rainfall ranged from 3 to $431 \mathrm{~mm}$ per day, with the lowest precipitation in February and the highest in July.

High SDT and low DO contributed most variation between sites during the northeasterly (December March) and intermediate (October November) monsoon, while low SDT and high DO contributed much variability during the southeasterly (March April) monsoon. Typhoon occurrence and low SDT as well as high rainfall and wind direction were influential during the southwesterly (May September) monsoon. PCA showed that the number of typhoons and low SDT dominated the first principal component $(51.6 \%$ variance), while the second principal component (17.2\% variance) was dominated by high SDT and low DO (Fig. 3).

Spatio-temporal analysis of zooplankton

A total of 15 rotifer, 6 cladoceran, and 3 copepod species were identified. One copepod (Pseudodiaptomus brehmi) was not included in the subsequent analyses due to its rarity. Overall, copepods made up $64 \%$ of average zooplankton abundance, followed by the rotifers $(27 \%)$ and cladocerans $(9 \%)$. In terms of biomass, the copepods contributed $84 \%$ of the total, while the cladocerans made up $14 \%$ and the rotifers $2 \%$.
Keratella tropica, Brachionus forficula, and Hexarthra intermedia were the most abundant and commonly occurring rotifers (Table 1) followed by B. havanaensis and Polyarthra vulgaris. A further 10 species either had low abundances or were rarely encountered in samples. Abundance was higher at FC sites for Filinia longiseta, $H$. intermedia, $K$. tropica $(P=0.009)$, and $P$. vulgaris $(P=0.002)$ (Fig. 4). Temporal variations were also observed in the abundances of the other rotifer species. Percentages of ovigerous individuals were low for all rotifer species, with more recorded in FC areas than in OW sites. B. falcatus had the highest percentage of eggbearing individuals in both $\mathrm{OW}$ and FC sites. The Brachionus Trichocerca quotient $\left(Q_{\mathrm{B} / \mathrm{T}}\right)$ for the year 2008 was seven.

\section{Microcrustaceans}

Microcrustacean abundance and biomass was initially higher in FC compared to OW sites which became more similar in the succeeding months. Nauplii were the most abundant forms among all taxa, followed by cyclopoid copepodites. Among the cladocerans, Ceriodaphnia cornuta and Bosmina fatalis had the highest abundance and biomass, respectively (Table 2).

Calanoid copepods (males, females, and copepodites), nauplii, B. fatalis, C. cornuta, and Diaphanosoma sarsi exhibited peak abundance in January 
Fig. 3 PCA plot of environmental variables: SDT, DO, temp., ave. wind dir. (Wind), typhoon occurrence $(\mathrm{T})$ and rainfall (RF) in 2008. Plus northeast monsoon, asterisk southwest monsoon, open square southeast monsoon, open circle intermediate season

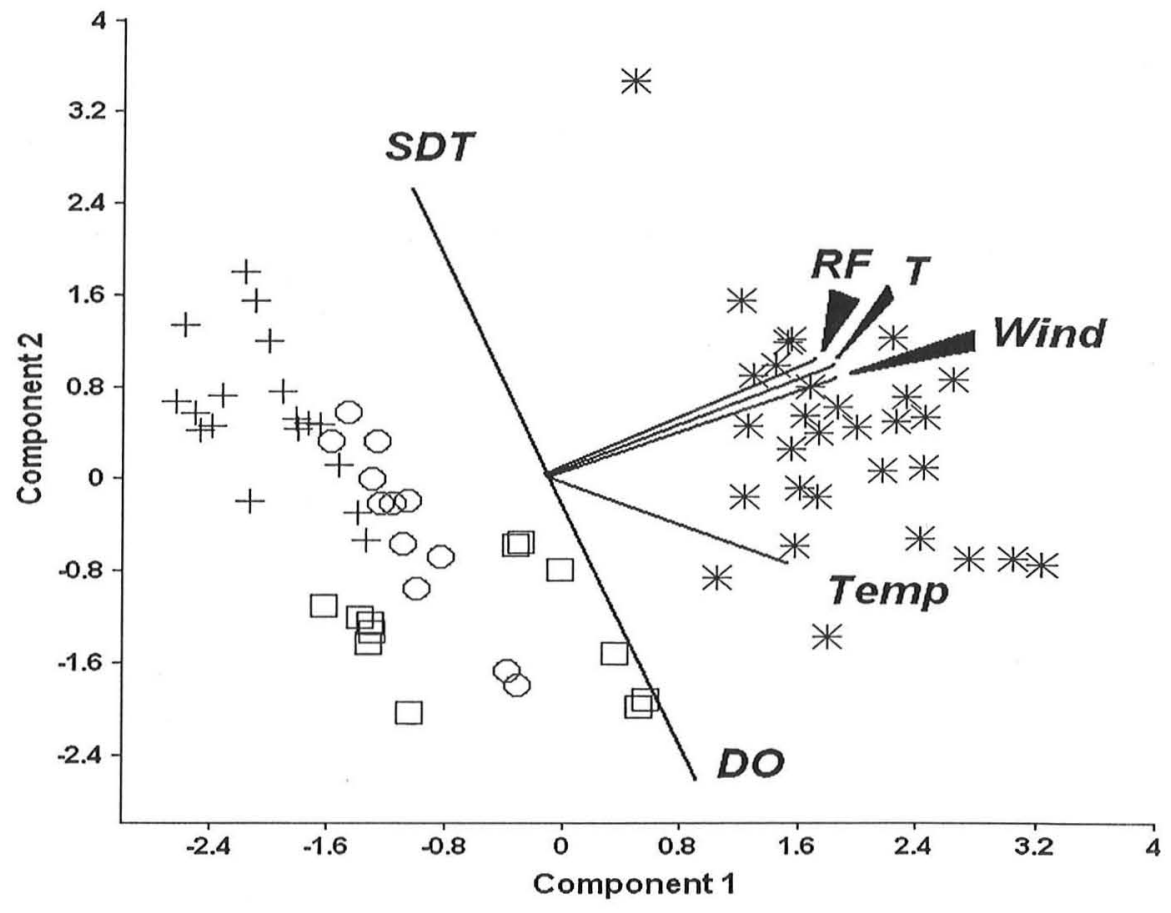

Table 1 Mean abundance, biomass, and frequency of occurrence of rotifer species from the open water (OW) and fish cage areas (FC) of Lake Taal

\begin{tabular}{|c|c|c|c|c|c|c|c|c|}
\hline & \multicolumn{2}{|c|}{ Average abundance (ind./l) } & \multicolumn{2}{|c|}{ Average biomass $(\mu \mathrm{g} / \mathrm{l})$} & \multicolumn{2}{|c|}{ Frequency occurrence } & \multicolumn{2}{|l|}{$P$ value } \\
\hline & OW & $\mathrm{FC}$ & OW & $\mathrm{FC}$ & OW & FC & Abundance & Biomass \\
\hline Keratella tropica & 30.9 & 57.4 & 4.0 & 7.5 & 100 & 100 & $0.009 *$ & $0.009^{*}$ \\
\hline Brachionus forficula & 24.7 & 30.0 & 5.4 & 6.6 & 100 & 100 & 0.916 & 0.916 \\
\hline Hexarthra intermedia & 30.0 & 66.8 & 6.9 & 15.4 & 100 & 100 & 0.011 & 0.011 \\
\hline Polyarthra vulgaris & 0.3 & 9.3 & 0.1 & 2.7 & 58 & 92 & $0.001 *$ & $0.001^{*}$ \\
\hline Brachionus havanaensis & 2.9 & 9.9 & 1.7 & 5.9 & 33 & 50 & 0.945 & 0.945 \\
\hline Brachionus falcatus' & 1.9 & 3.2 & & & 66 & 75 & 0.335 & \\
\hline Brachionus quadridentatus & 0.0 & 0.0 & & & 0 & 8 & & \\
\hline Brachionus angularis' & 0.1 & 0.5 & & & 17 & 25 & 0.561 & \\
\hline Brachionus diversicornis' $^{\prime}$ & 0.2 & 0.8 & & & 25 & 25 & 0.548 & \\
\hline Brachionus calyciflorus' & 0.1 & 0.6 & & & 25 & 25 & 1.0 & \\
\hline Filinia opoliensis & 1.0 & 1.6 & & & 75 & 67 & & \\
\hline Filinia longiseta & 0.1 & 0.9 & & & 42 & 83 & & \\
\hline Lecane bulla & 0.1 & 0.0 & & & 17 & 0 & & \\
\hline Anuraeopsis navicula & 1.0 & 1.5 & & & 67 & 67 & & \\
\hline Trichocerca capucina' & 0.1 & 2.2 & & & 33 & 33 & 0.118 & \\
\hline Total & 94.3 & 184.7 & 18.2 & 38.1 & & & & \\
\hline
\end{tabular}

$\left.{ }^{\prime}\right)$ Denotes species whose abundance peaks were selected prior to statistical analysis. Significance was accepted at $P<0.01$, indicated by an asterisk

(Fig. 5). C. cornuta, B. fatalis, M. micrura, Diaphanosoma spp., and copepods had higher densities in FC sites in January and February compared to OW sites.
Male and female calanoid copepods exhibited similar occurrence and abundance peaks, whereas in cyclopoids, females were more abundant than males. Peak 

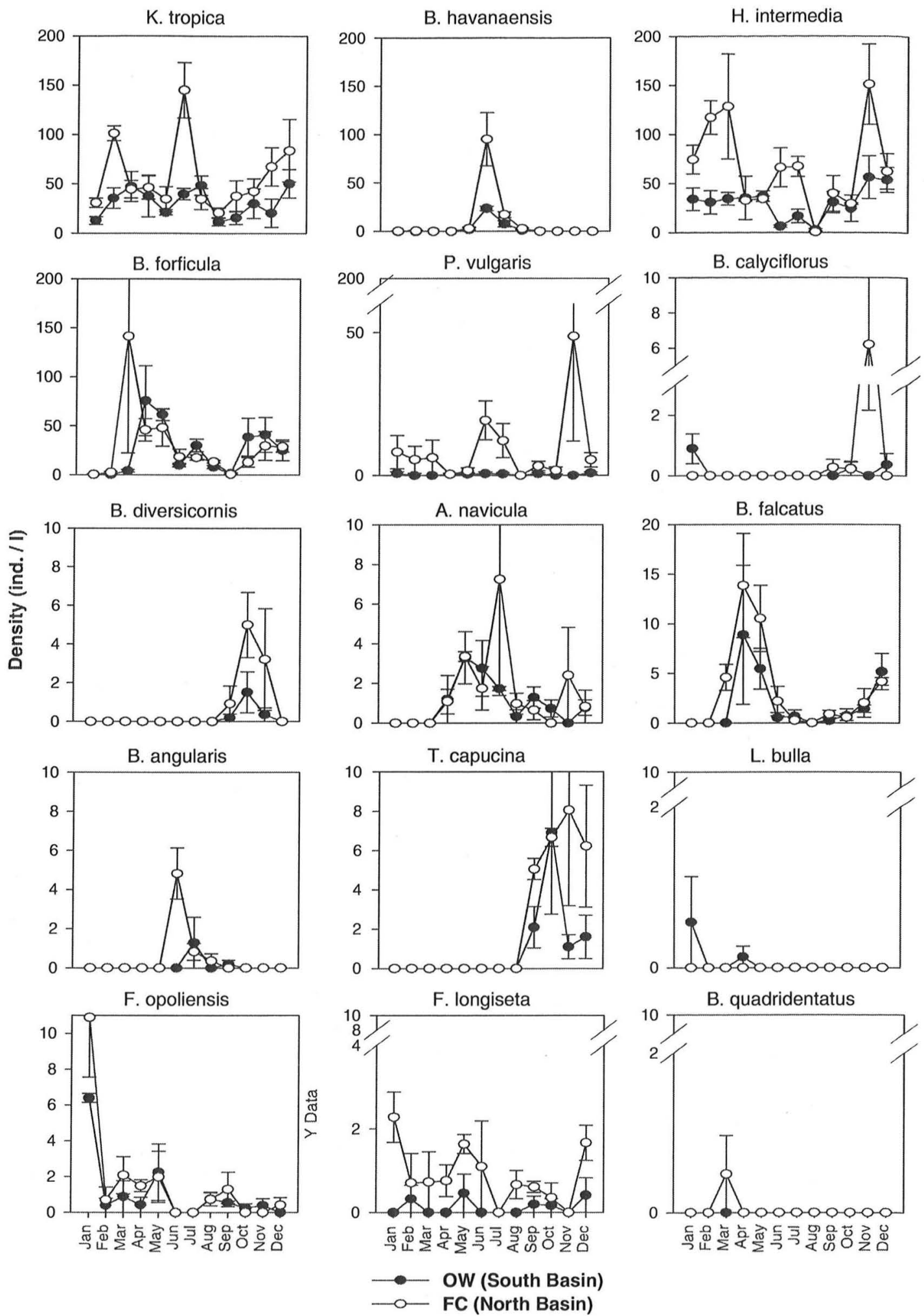

Fig. 4 Rotifer densities from open water (OW) and fish cage (FC) areas of Lake Taal in 2008. Note differences in $y$ axis values used 
Table 2 Monthly averages of abundance, biomass, frequency of occurrence, and $P$ values of microcrustaceans from the open water (OW) and fish cage areas (FC) of Lake Taal, collected in 2008

\begin{tabular}{|c|c|c|c|c|c|c|c|c|}
\hline & \multicolumn{2}{|c|}{ Average abundance (ind./l) } & \multicolumn{2}{|c|}{ Average biomass $(\mu \mathrm{g} / \mathrm{l})$} & \multicolumn{2}{|c|}{ Frequency of occurrence } & \multicolumn{2}{|l|}{$P$ value } \\
\hline & OW & $\mathrm{FC}$ & OW & $\mathrm{FC}$ & OW & $\mathrm{FC}$ & Abundance & Biomass \\
\hline Nauplii & 95.6 & 199.5 & 103.7 & 216.5 & 100 & 100 & 0.577 & 0.577 \\
\hline Calanoid Copepodite & 35.1 & 43.0 & 366.8 & 450.1 & 100 & 100 & 0.95 & 0.95 \\
\hline Cyclopoid Copepodite & 87.0 & 83.0 & 263.2 & 251.2 & 100 & 100 & 0.579 & 0.579 \\
\hline Calanoid female & 4.3 & 6.4 & 187.5 & 280.9 & 75 & 83 & 0.42 & 0.42 \\
\hline Calanoid male & 3.0 & 5.4 & 65.0 & 116.0 & 58 & 83 & 0.21 & 0.21 \\
\hline Cyclopoid female & 29.4 & 26.5 & 185.5 & 167.3 & 100 & 100 & 0.849 & 0.849 \\
\hline Cyclopoid male & 13.7 & 11.8 & 46.7 & 40.4 & 100 & 100 & 0.419 & 0.419 \\
\hline Ceriodaphnia cornuta & 36.7 & 54.8 & 23.5 & 35.0 & 100 & 100 & 0.207 & 0.207 \\
\hline Moina micrura & 7.3 & 15.8 & 44.0 & 94.8 & 100 & 100 & 0.015 & 0.015 \\
\hline Bosmina fatalis & 19.8 & 32.2 & 47.2 & 77.4 & 100 & 100 & 0.893 & 0.893 \\
\hline Diaphanosoma excisum & 3.9 & 5.1 & 6.0 & 7.9 & 67 & 100 & 0.31 & 0.31 \\
\hline Diaphanosoma sarsi & 3.6 & 5.0 & 14.5 & 20.2 & 92 & 100 & 0.941 & 0.941 \\
\hline Diaphanosoma tropicum & 2.2 & 2.1 & 9.0 & 8.4 & 67 & 92 & 0.984 & 0.984 \\
\hline Total & 341.4 & 490.7 & 1362.6 & 1766.0 & & & & \\
\hline
\end{tabular}

Average abundances of M. micrura and B. fatalis were higher in FC sites due to high densities in January (B. fatalis) and January to March (M. micrura)

abundance for cyclopoids was observed in July for females and in August for males. Calanoid copepodites were generally less abundant than cyclopoids. Calanoid copepodite abundance peaked in April in OW sites, while cyclopoids were most abundant in March. Naupliar abundance peaked in January at 1,300 ind./l in $\mathrm{FC}$ sites but then remained below 300 ind./l for the rest of the year.

Bosmina fatalis, Moina micrura, and Ceriodaphnia cornuta recorded the highest percentage of eggbearing individuals, while Diaphanosoma spp. had the lowest (Fig. 6). Of all female copepods recorded throughout the entire year, fewer than 5\% were eggbearers (Table 3). The calanoid to cladocera + cyclopoid ratio was low for all sampling months, reaching a maximum of 0.5 in May, while no calanoids were observed in October.

Multivariate analysis

The CCA bi-plot showed how the sites grouped together based on the presence of $\mathrm{FCs}$ as well as physico-chemical variables such as DO, temperature, and SDT (Fig. 7). There was a clear distinction between sites 1 and $3(\mathrm{OW})$ and 4 and $6(\mathrm{FC})$. The different zooplankton taxa included clustered near the center of the bi-plot. Bray Curtis Cluster Analysis confirmed the results of CCAs and the spatiotemporal analyses of zooplankton distribution. The taxa which had more variable abundances between OW and FC sites grouped together (Fig. 8). The nauplii, cyclopoid copepods, copepodites, $C$. cornuta, B. fatalis, K. tropica, and H. intermedia formed one group, while the calanoid copepods, D. sarsi, D. excisum, D. tropicum, and B. havanaensis formed another.

\section{Discussion}

It was hypothesized that $\mathrm{FC}$ sites may exhibit different zooplankton abundance and community composition compared to OW sites. Nutrient inputs from uneaten fish feed, increased microbial activity in the lake bottom, and a decrease in water quality have been noted in the vicinity of FCs in Lake Taal (Alcañices et al., 2001; Vista et al., 2006; Perez et al., 2008; Hallare et al., 2009). The density of FCs in the north basin has already exceeded the lake's carrying capacity (White et al., 2007). We observed higher SDT and DO in the OW compared to the FC areas, 


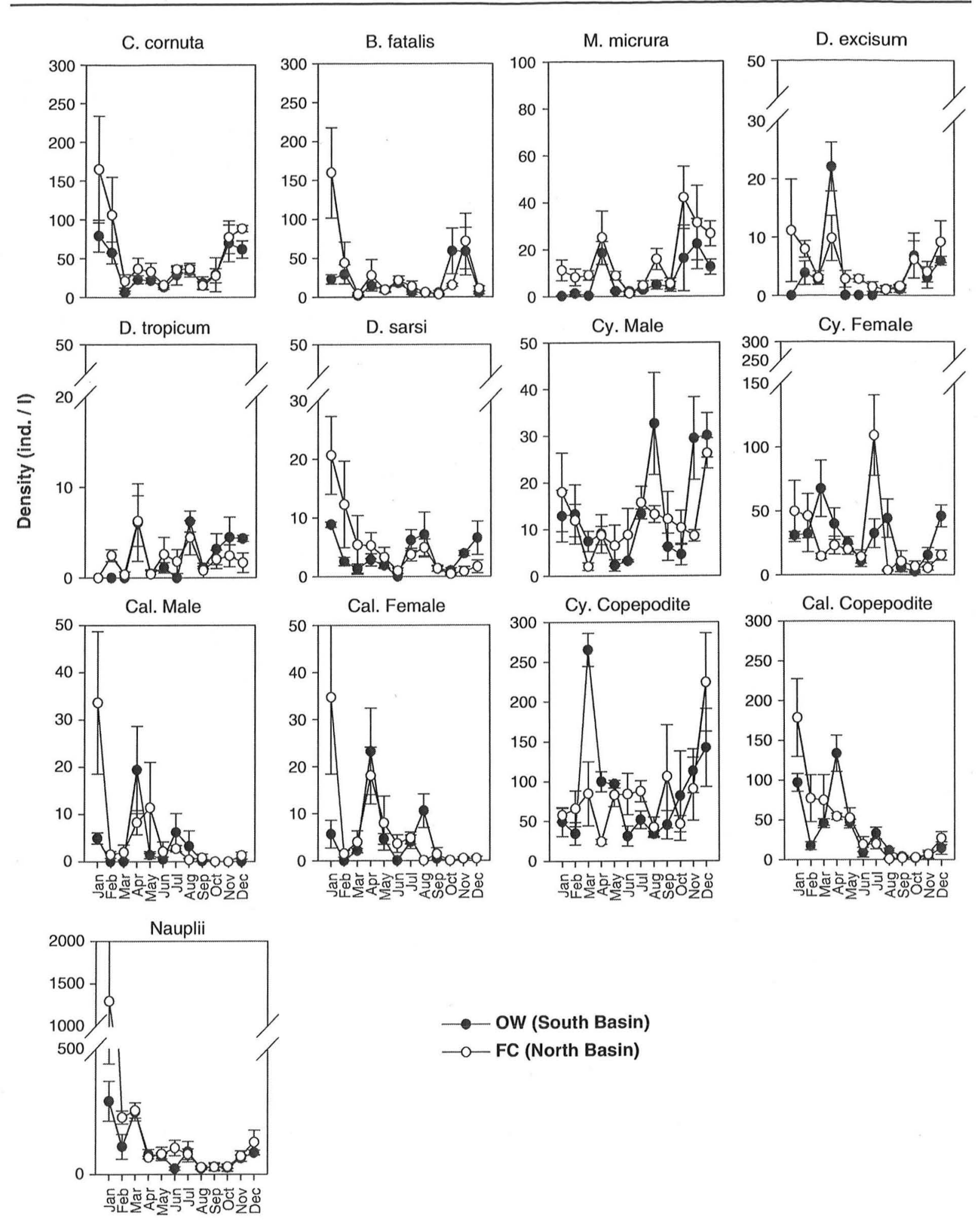

Fig. 5 Microcrustacean densities from open water (OW) and fish cage (FC) areas of Lake Taal in 2008. Note differences in $y$ axis values used 
Fig. 6 The monthly percentage of ovigerous microcrustacean females recorded during 2008. Note different $y$ axis used for D. excisum
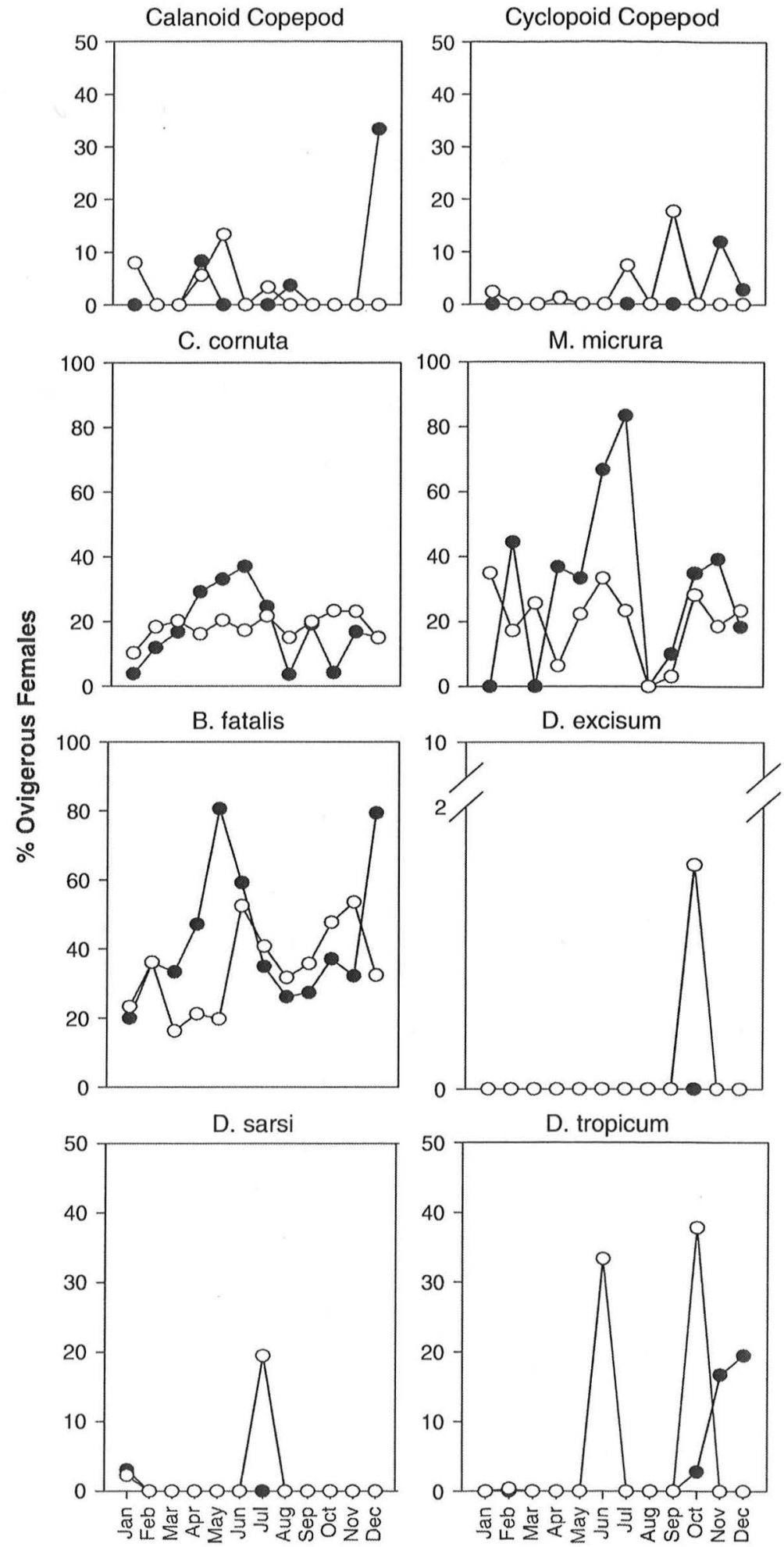

- OW (South Basin)

FC (North Basin) 
Table 3 Average percentage of ovigerous rotifer and micro crustacean females in monthly samples collected from Lake Taal in 2008 from open water (OW) and fish cage (FC) sites

\begin{tabular}{lrr}
\hline & \multicolumn{2}{c}{ Percentage } \\
\cline { 2 - 3 } & OW & FC \\
\hline K. tropica & 3.7 & 4.0 \\
B. forficula & 2.7 & 6.8 \\
B. havanaensis & 1.9 & 3.3 \\
H. intermedia & 1.9 & 0.4 \\
P. vulgaris & 0.0 & 2.4 \\
Calanoid Copepod & 3.8 & 2.5 \\
Cyclopoid Copepod & 1.3 & 2.4 \\
C. cornuta & 17.9 & 18.3 \\
M. micrura & 30.6 & 19.7 \\
B. fatalis & 42.8 & 34.2 \\
D. excisum & 0.0 & 0.1 \\
D. sarsi & 0.3 & 1.8 \\
D. tropicum & 6.0 & 6.0 \\
\hline
\end{tabular}

Fig. 7 Canonical correspondence analysis of the six sampling sites in Lake Taal (1 3 OW, 46 FC). Each point represents one zooplankton taxa that have been included in the analysis. Secchi disk transparency (SDT), dissolved oxygen (DO), temperature (TEMP), and number of fish cages (FC) were used as environmental variables suggesting higher turbidity due to uneaten feed and fish feces and/or higher primary production due to high-nutrient input. Overall, the zooplankton community showed similar species composition for an entire year in both parts of the lake (Tables 1, 2). However, higher abundances were found in FC sites either during the first few months (microcrustaceans) or throughout most of the year (rotifers).

The higher nutrient levels in FC sites may have promoted increased primary productivity which in turn led to higher zooplankton densities; however, the lack of spatial differences in the distribution of zooplankton may be attributable to the influence of wind and rainfall in dispersing plankton and nutrients. Limnological characteristics unique to tropical regions such as the formation and dissipation of thermoclines in tropical lakes (atelomixis) are strongly influenced by wind-induced water movements and temperature inversions caused by rainfall (Lewis Jr., 1996). Lake Taal lies only $2.5 \mathrm{~m}$ above

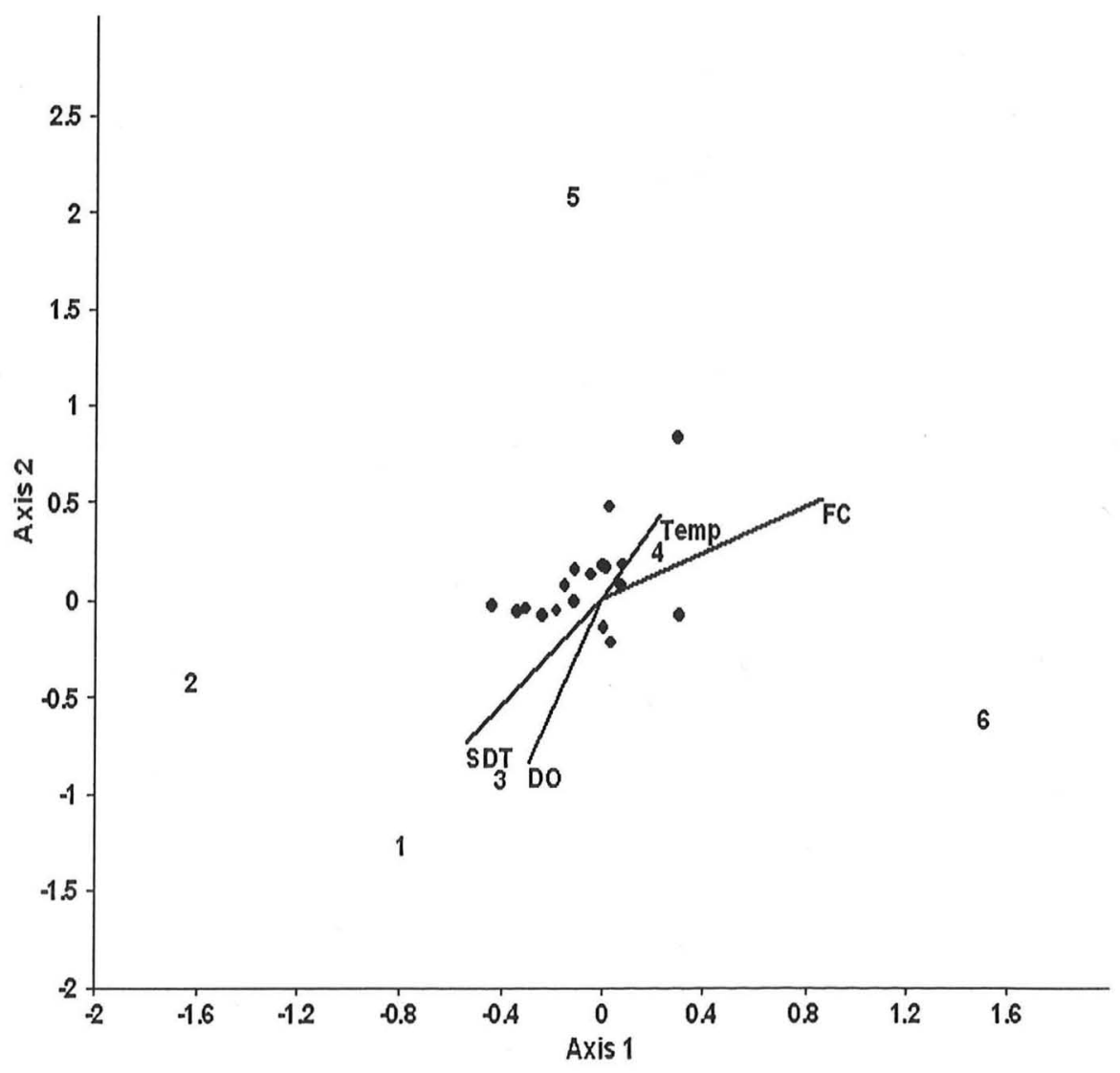


Fig. 8 Cluster analysis

based on Bray Curtis

similarity matrices of

zooplankton biomass in the

sampling sites of Lake Taal.

Keratella tropica Kt,

Brachionus forficula Brf,

Hexarthra intermedia $\mathrm{Hi}$,

Polyarthra vulgaris $\mathrm{Pv}$,

Brachionus havanaensis

Brh, Nauplii n, Calanoid

Copepodite $\mathrm{ClC}$

Cyclopoid Copepodite

$\mathrm{CyC}$, Calanoid female

$\mathrm{ClF}$, Calanoid male CIM,

Cyclopoid female CyM,

Cyclopoid male CyM

Ceriodaphnia cornuta $\mathrm{Cc}$,

Moina micrura $\mathrm{Mm}$,

Bosmina fatalis $\mathrm{Bf}$,

Diaphanosoma excisum

De, Diaphanosoma sarsi

Ds, Diaphanosoma

tropicum Dt

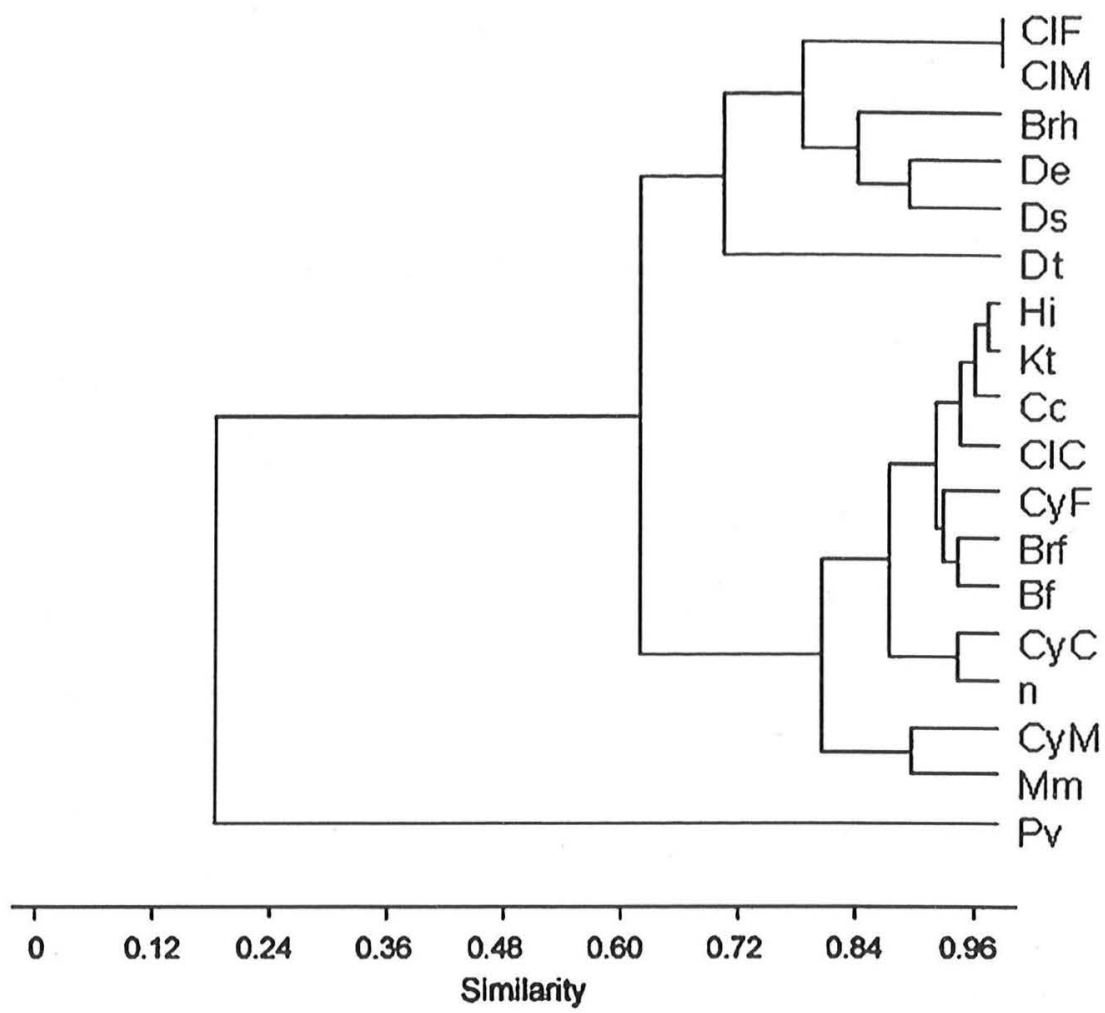

sea level, and the uneven height of the caldera ridges makes it prone to strong winds. Wind-induced currents are important in determining the distribution of epilimnetic larval fish, phyto- and zooplankton (Rinke et al., 2009), and in Lake Taal, their influence is likely to be even greater due to the smaller size of tropical zooplankton (Fernando, 1980). Lake mixing, which coincides with the northeast monsoon (December to February), may have been the reason why the higher abundances of microcrustaceans in FC sites only happened during the earlier part of the year as it can aid the dispersal of both plankton and nutrients from areas with higher concentrations. The onset of the southwesterly monsoon where there is higher rainfall and stronger wind from typhoons further supported this. Nutrient run-offs from the sediments during periods of heavy rainfall also increase the amount of nutrients entering the lake (White \& San Diego-Mcglone, 2008). The principal component analysis shows how the physical and chemical variables in the lake were influenced by the monsoon seasons (Fig. 3). This may have further supported phytoplankton populations in OW sites which led to the comparable densities of the microcrustaceans in the OW and FC sites.

Lake mixing, wind currents, and increased rainfall may not have played a prominent role in determining the abundance and distribution of rotifers as they were found in higher densities in FC sites even after lake mixing. Results of the Kruskal Wallis ANOVA revealed higher abundances in FC sites compared to OW sites for $K$. tropica and P. vulgaris, while $F$. longiseta and $H$. intermedia occurred in higher numbers in FC sites in most months albeit the differences were not significant for abundance values. Canonical correspondence analysis showed that abundance did not vary significantly between OW and FC sites except for five taxa which were more associated with FC sites (copepod nauplii and four rotifer species $B$. havanaensis, $H$. intermedia, $P$. vulgaris, and $K$. tropica). They either had high abundances in FC sites in 1 month (copepod nauplii and $B$. havanaensis) or in several months $(H$. intermedia, $P$. vulgaris, and $K$. tropica). Cluster analysis then confirmed that taxa with similar distributions formed distinct groupings. Those with higher 
densities in FC sites were more closely related with one another, while those that had similar densities between $\mathrm{OW}$ and FC sites were found in the other group. The abundance of dominant rotifers in $\mathrm{FC}$ sites may be due their tolerance for more eutrophic environments. Previous studies have used rotifer abundance and occurrence as efficient bioindicators of higher trophic levels (Sládecek, 1983; Saksena, 1987). Shorter generation times under favorable conditions may have supported their population in FC sites in spite of their being easily transported to other areas of the lake because of their small size. There is also reduced predation risk for rotifers in FC sites from lower water transparency. Their smaller size and defense mechanisms such as harder lorica and effective escape behavior also help protect them from predators in FC sites (Walz, 1995).

Our data also show that Lake Taal zooplankton exhibited continuous recruitment and reduced seasonality similar to that observed in other tropical lakes (Hart, 1985; Mengestou \& Fernando, 1991; Gliwicz, 1999; Vijverberg et al., 2008). Atelomixis resets the successional clock and causes numerous discrete successional episodes which can take place within a matter of days (Lewis Jr., 1984). This may be the main reason for the lack of pronounced seasonality observed in the abundance and distribution of dominant taxa in the current study. Copepod reproduction continued year round, as evidenced by the presence of nauplii and copepodites in all months, and the appearance of number of ovigerous individuals in all months. However, an increase in the percentage of egg-bearing females toward the end of the year may explain the greater abundance of nauplii observed in January. $C$. cornuta and $B$. fatalis had a larger proportion of ovigerous individuals than copepods but these were likewise recorded in all months. The dominant rotifer species exhibited high frequencies of occurrence and ovigerous individuals were recorded in most months. Only rare rotifer taxa such as A. navicula, B. angularis, T. capucina, $B$. diversicornis, $B$. falcatus, and $B$. calyciflorus exhibited obvious seasonal succession. Some appeared after the mixing period ( $F$. opoliensis and $B$. falcatus), others after the onset of the rainy season (A. navicula, B. angularis), while the rest peaked in abundance during the start of the northeasterly monsoon $(B$. diversicornis, $B$. calyciflorus, and T. capucina). These rare species occurred in both areas, though some had higher abundances in FC sites similar to the abundances of dominant rotifer species.

Predation by Sardinella tawilis may have an influence on zooplankton abundance and distribution. S. tawilis is the dominant pelagic fish species in Lake Taal and is an efficient size-selective zooplanktivore (Papa et al., 2008). Their largest available prey would be the adult female calanoid and cyclopoid copepods, Moina micrura and Diaphanosoma spp. We observed a decrease in biomass of adult and copepodite calanoid copepods, the biggest cladocerans (Diaphanosoma and Moina) and female cyclopoid copepods from April to June, consistent with the period of increased feeding by S. tawilis (Papa et al., 2008). This drop in zooplankton abundance may be a product of predation at both FC and OW sites. Pelagic fish, mainly $S$. tawilis, which prey on large microcrustacean zooplankton, are present in both sites (Aypa et al., 2008). Cultured and escaped Oreochromis spp. (Nile tilapia) and Chanos chanos (milkfish) particularly the juveniles also contribute to this. A similar decline was not observed for the rotifers, which are not a preferred prey of S. tawilis (Papa et al., 2008). Some rotifer species, such as A. navicula, B. havanaensis, and B. angularis, even showed abundance peaks that coincided with the drop in cladoceran and copepod biomass, suggesting that these species benefited from reduced competition by the larger taxa.

After analyzing the spatial and temporal abundance and distribution of zooplankton, we compared our data on species composition with those from earlier studies. Lake Taal seems to have been nutrient rich or capable of supporting eutrophic species prior to the introduction of FCs. The five Brachionus species recorded in 1941 (Woltereck et al., 1941) are indicative of eutrophic conditions (Saksena, 1987). The $Q_{\mathrm{B} / \mathrm{T}}$ in 1941 was only two points lower than the current value of seven. Values higher than two indicate eutrophic environments (Sládecek, 1983), so this parameter suggests that the lake was already eutrophic before aquaculture operations began.

The trophic levels of aquatic ecosystems have also been characterized using the presence and dominance of certain copepod species (Dussart \& Defaye, 2001). Earlier studies in Lake Taal recorded only cyclopoids and cladocerans (Kiefer, 1939; Woltereck et al., 1941). These taxa are generally favored in eutrophic environments ( $\mathrm{Ka}$ et al., 2006), while calanoids 
typically decrease in number with increasing productivity (Adrian, 1997; Pinto-Coelho et al., 2005; Ka et al., 2006). These previous findings are supported by our own data, which indicate a low calanoid to cladocera + cyclopoid ratio. Data published in 1992 and 2008 (collected in 1998) agree with the findings of the current study, that copepods were the most abundant major zooplankton taxa in Lake Taal (Zafaralla, 1992; Vijverberg et al., 2008). Hence, both current and historic analyses of the microcrustacean community in Lake Taal support the implications of earlier analyses of rotifer abundance, that the lake had eutrophic tolerant species as early as the 1940s. Utilizing available data on rotifer and microcrustacean composition is a useful alternative in evaluating the lake's trophic status in the absence of physico-chemical data such as Chl $a$ and tot-P. No data on these parameters exist prior to 1976 .

Summarizing the available information on the biological indicators of trophic status, we suggest that Lake Taal was nutrient rich, even prior to the introduction of the FCs. Recent studies on nutrient levels, however, confirm the role of FCs in accelerating the rate at which Lake Taal is undergoing eutrophication. Aquaculture contributed $82 \%$ to external phosphorous input in the year 2001 (Alcañices et al., 2001; Vista et al., 2006). Total phosphorous (tot-P) values were already within eutrophic levels in 1973 (Vista et al., 2006), 2 years prior to the start of aquaculture. The lowest tot-P level recorded was in 1998, at $0.19 \mathrm{mg} / \mathrm{l}$ (Perez et al., 2008). Data from the FISHSTRAT study showed maximum Chl $a$ levels at $50 \mu \mathrm{g} / \mathrm{l}$ in April 2000 (Perez et al., 2008) while the Akvaplan-niva survey had Chl $a$ levels reaching a maximum of $10 \mu \mathrm{g} / \mathrm{l}$ at $10 \mathrm{~m}$ depth even in OW sites (White et al., 2007). Lakes with more than $0.035 \mathrm{mg} / \mathrm{l}$ tot-P and $10 \mu \mathrm{g} / \mathrm{l} \mathrm{Chl} a$ are considered eutrophic (Hakanson, 1980).

The suspected eutrophic state prior to the introduction of FCs may be a result of volcanism. Volcanic bottom layers show geothermal activity and are nutrient rich, releasing fluxes of geomorphic P into the water (Golterman, 1973; Talling \& Lemoalle, 1998; Ramos, 2002; Amarasinghe et al., 2008; Gunkel \& Beulker, 2009). Some suspected thermal vents in Lake Taal are located in the OW areas (Ramos, 2002), and their geothermal activity may enhance vertical mixing and contribute to increased primary and secondary production (Amarasinghe et al., 2008), even in areas not subject to aquacultural inputs. In Lake Taal, hydrochemical conditions and mixing patterns are greater influences to phytoplankton productivity compared to other factors such as zooplankton grazing (Rott et al., 2008). Similarly, in other caldera lakes such as Lake Cuicocha (Ecuador) and Crater Lake (USA), zooplankton occurs down to deeper waters due to increased mixing from thermal vents (Gunkel \& Beulker, 2009; Larson et al., 2009). Analyzing the zooplankton community of tropical volcanic lakes such as Lake Taal may help better understand the negative impact of increased primary production in FC areas. For example, the lack of variation in zooplankton composition and the similar abundances of microcrustaceans between FC and OW sites of the lake suggest that the effects of increased nutrient input from aquaculture are not restricted to fish culture areas but may affect the lake as a whole due to wind-induced water exchange between the FC and $\mathrm{OW}$ basins, while the abundance of certain rotifer species in FC sites confirms the role of aquaculture in further increasing nutrient levels since these rotifers are indicators of higher trophic conditions.

Acknowledgments We would like to acknowledge Mrs. Amy Jane Beer for language editing, the Philippine Atmospheric, Geophysical and Astronomical Services Administration (PAGASA) Weather Station in Tanauan City and the Batangas Provincial Government Environment and Natural Resources Office (PGENRO) for providing secondary data. The German Academic Exchange Service (DAAD), Tonolli Fund Postgraduate Fellowship of the International Society of Limnology (SIL), Philippine Commission on Higher Education (CHED) and the University of Santo Tomas (UST) provided funds to the first author to conduct this research. This study was completed while the first author was at the Limnological Institute of the University of Konstanz as a German Academic Exchange Service (DAAD) Research Fellow.

\section{References}

Adrian, R., 1997. Calanoid cyclopoid interactions: evidence from an 11 year field study in a eutrophic lake. Freshwater Biology 38: 315325 .

Alcanices, M. M., R. C. Pagulayan \& A. C. Mamaril Sr., 2001. Impact assessment of cage culture in Lake Taal, Philip pines. In Santiago, C. B., M. L. Cuvin Aralar \& Z. U. Basiao (eds), Conservation and Ecological Manage ment of Philippine Lakes in Relation to Fisheries and Aquaculture. SEAFDEC, PCAMRD and BFAR, Quezon City: $153 \mathrm{pp}$. 
Amarasinghe, P. B., M. G. Ariyarantne, T. Chitapalapong \& J. Vijverberg, 2008. Production, Biomass and Productivity of Copepods and Cladocerans in Tropical Asian Water Bodies and the Carrying Capacity for Zooplanktivorous Fish. In Schiemer, F., D. Simon, U. S. Amarasinghe \& J. Moreau (eds), Aquatic Ecosystems and Development: Comparative Asian Perspectives. Biology of Inland Waters Series. Backhuys Publishers, Leiden: 173194.

Aypa, S. M., S. Ingthamjitr, U. S. Amarasinghe, D. Simon \& C. De Jesus, 2008. Fish cage culture in Asian lakes and reservoirs: potentials and constraints. In Schiemer, F., D. Simon, U. S. Amarasinghe \& J. Moreau (eds), Aquatic Ecosystems and Development: Comparative Asian Per spectives. Biology of Inland Waters Series. Backhuys Publishers, Leiden: 305338.

Borges, P., S. Train, J. Dias \& C. Bonecker, 2010. Effects of fish farming on plankton structure in a Brazilian tropical reservoir. Hydrobiologia 649: 279291 .

Dussart, B. H. \& D. Defaye, 2001. Introduction to the Copepoda. Backhuys Publishers, Leiden.

Fernando, C. H., 1980. The species and size composition of tropical freshwater zooplankton, with special reference to the oriental region (South East Asia). Internationale Revue der Gesamten Hydrobiologie und Hydrogeographie 65: 411425 .

Fernando, C. H., 2002. A Guide to Tropical Freshwater Zoo plankton Identification, Ecology and Impact on Fisher ies. Backhuys Publishers, Leiden.

Gliwicz, Z. M., 1999. Predictability of seasonal and diel events in tropical and temperate lakes and reservoirs. In Tundisi, J. G. \& M. Straskraba (eds), Theoretical Reservoir Ecol ogy and Its Applications. International Institute of Ecol ogy, Brazilian Academy of Sciences and Backhuys Publishers, Leiden: 99124.

Golterman, H. L., 1973. Natural phosphate sources in relation to phosphate budgets: a contribution to the understanding of eutrophication. Water Research 7: 317.

Gunkel, G. \& C. Beulker, 2009. Limnology of the Crater Lake Cuicocha, Ecuador, a cold water tropical lake. Interna tional Review of Hydrobiology 94: 103125.

Hakanson, L., 1980. An ecological risk index for aquatic pol lution control a sedimentological approach. Water Research 14: 9751001.

Hallare, A. V., P. A. Factor, E. K. Santos \& H. Hollert, 2009. Assessing the impact of fish cage culture on Taal Lake (Philippines) water and sediment quality using the zeb rafish embryo assay. Philippine Journal of Science 138: 91104.

Hart, R. C., 1985. Seasonality of aquatic invertebrates in low latitude and southern hemisphere inland waters. Hydro biologia 125: 151178 .

Ka, S., M. Pagano, N. Ba, M. Bouvy, C. Leboulanger, R. Arfi, O. T. Thiaw, E. H. M. Ndour, D. Corbin, D. Defaye, C. Cuoc \& E. Kouassi, 2006. Zooplankton distribution related to environmental factors and phytoplankton in a shallow tropical lake (Lake Guiers, Senegal, West Africa). Inter national Review of Hydrobiology 91: 389405.

Kiefer, F., 1939. von der Wallacea Expedition gesammelten Arten der Gattungen Thermocyclops Kiefer. Internatio nale Revue der gesamten Hydrobiologie und Hydrogra phie 39: 5474 .
Larson, G. L., R. Hoffman, C. D. Mcintire, G. Lienkaemper \& B. Samora, 2009. Zooplankton assemblages in montane lakes and ponds of Mount Rainier National Park, Wash ington State, USA. Journal of Plankton Research 31(3): 273285.

Lewis Jr., W. M., 1979. Zooplankton Community Analysis: Studies on a Tropical Ecosystem. Springer, New York.

Lewis Jr., W. M., 1984. A five year record of temperature, mixing, and stability for a tropical lake (Lake Valencia, Venezuela). Archiv fur Hydrobiologie 104: 337343.

Lewis Jr., W. M., 1996. Tropical lakes: how latitude makes the difference. In Schiemer, F. \& K. T. Boland (eds), Per spectives in Tropical Limnology. SPB Academic Pub lishing, Amsterdam: 4364.

Lewis Jr., W. M., 2000. Basis for the protection and manage ment of tropical lakes. Lakes and Reservoirs: Research and Management 5: 3548.

Mamaril Sr., A. C., 1986. Zooplankton guide to Philippine flora and fauna. NRMC and UP Diliman, Quezon City. 268 pp.

Mamaril Sr., A. C., 2001. Translocation of the Clupeid Sardinella Tawilis to another lake in the Philippines: a proposal and ecological considerations. In Santiago, C. B., M. L. Cuvin Aralar \& Z. U. Basiao (eds), Conservation and Ecological Management of Philippine Lakes in Relation to Fisheries and Aquaculture. SEAFDEC, PCAMRD and BFAR, Quezon City: 133147.

Mamaril Sr., A. C. \& C. H. Fernando, 1978. Freshwater Zoo plankton of the Philippines: Rotifera, Cladocera and Copepoda. Natural and Applied Science Bulletin 30: 109221.

Mengestou, S. \& C. H. Fernando, 1991. Seasonality and abundance of some dominant crustacean zooplankton in Lake Awasa, a tropical rift valley lake in Ethiopia. Hyd robiologia 226: 137152.

Papa, R. D. S., R. C. Pagulayan \& A. E. J. Pagulayan, 2008. Zooplanktivory in the endemic freshwater sardine, Sardinella tawilis (Herre 1927) of Taal Lake, the Philip pines. Zoological Studies 47: 535543.

Perez, T., E. E. Enriquez, R. D. Guerrero Iii, D. Simon \& F. Schiemer, 2008. Catchment characteristics, hydrology, limnology and socio economic features of Lake Taal, Philippines. In Schiemer, F., D. Simon, U. S. Amarasinghe \& J. Moreau (eds), Aquatic Ecosystems and Development: Comparative Asian Perspectives. Biology of Inland Waters Series. Backhuys Publishers, Leiden: 6380.

Petersen, F., 2007. An Illustrated Key to the Philippine Freshwater Zooplankton. Including Some Brackish Water Species from Laguna De Bay. With Ecological Notes.

Pinto Coelho, R., B. Pinel Alloul, G. Méthot \& K. E. Havens, 2005. Crustacean zooplankton in lakes and reservoirs of temperate and tropical regions: variation with trophic status. Canadian Journal of Fisheries and Aquatic Sci ences 62: 348361 .

Ramos, E. G., 2002. Origin and geologic features of Taal Lake, Philippines. Aquatic Ecosystem Health \& Management 5: 155162.

Rinke, K., A. M. R. Huber, S. Kempke, M. Eder, T. Wolf, W. N. Probst \& K. O. Rothhaupt, 2009. Lake wide dis tributions of temperature, phytoplankton, zooplankton, and fish in the pelagic zone of a large lake. Limnology and Oceanography 54: 13061322. 
Rott, E., E. I. L. Silva, E. E. Enriquez \& S. Ingthamjitr, 2008. Phytoplankton community structure with special reference to species diversity in five tropical Asian Water Bodies. In Schiemer, F., D. Simon, U. Amarasinghe \& J. Moreau (eds), Aquatic Ecosystems and Development: Compara tive Asian Perspectives. Backhuys Publishers, Leiden: 81120.

Saksena, D. N., 1987. Rotifers as indicators of water quality. Acta Hydrochimica et Hydrobiologia 15: 481485.

Sládecek, V., 1983. Rotifers as indicators of water quality. Hydrobiologia 100: 169201.

Sousa, W., J. L. Attayde, E. D. S. Rocha \& E. M. Eskinazi Sant'anna, 2008. The response of zooplankton assem blages to variations in the water quality of four man made lakes in semi arid northeastern Brazil. Journal of Plankton Research 30: 699.

Talling, J. F. \& J. Lemoalle, 1998. Ecological Dynamics of Tropical Inland Waters. Cambridge University Press, London.

Tvpl Pamb, 2009. Taal volcano protected landscape manage ment plan. Batangas: 67.

Unger, P. A. \& W. M. Lewis Jr., 1991. Population ecology of a pelagic fish, Xenomelaniris venezuelae (Atherinidae), in Lake Valencia, Venezuela. Ecology 72: 440456.

Urabe, J., 1992. Midsummer succession of rotifer plankton in a shallow eutrophic pond. Journal of Plankton Research 14: 851.

Vijverberg, J., P. B. Amarasinghe, T. Chitapalapong, R. C. Pagulayan, M. G. Ariyarantne, E. R. J. Pamanian, E. I. L. Silva \& L. A. J. Nagelkerke, 2008. Structure of microcrustacean zooplankton communities in five tropical Asian water bodies. In Schiemer, F., D. Simon, U. S. A marasinghe \& J. Moreau (eds), Aquatic Ecosystems and Development: Comparative Asian Perspectives. Biology of Inland Waters Series. Backhuys Publishers, Leiden: 153172.
Vista, A., P. Norris, F. Lupi \& R. Bernsten, 2006. Nutrient loading and efficiency of tilapia cage culture in Taal Lake, Philippines. Philippine Agricultural Scientist 89: 4857.

Walz, N., 1995. Rotifer populations in plankton communities: energetics and life history strategies. Experientia 51: 437453.

Wetzel, R. B. \& G. E. Likens, 1991. Limnological Analysis. Springer, New York.

White, P., G. N. Christensen, R. Palerud, T. Legovic, W. R. Rosario, N. Lopez, R. R. Regpala, S. Gecek \& J. Hernandez, 2007. Environmental Monitoring and Modeling of Aquaculture in Risk Areas of the Philippines (Emma). Final Report, Taal Lake: 39 pp.

White, P. \& L. M. San Diego Mcglone, 2008. Ecosystem based approach to aquaculture management. Science Diliman 20: 110.

Woltereck, R., W. S. Tressler \& D. M. Bunag, 1941. Die Seen und Inseln der "Wallacea" Zwischenregion und ihre en demische Tierwelt. Internationale Revue der gesamten Hydrobiologie und Hydrographie 30: 3776.

Zafaralla, M. T., 1992. Limnological Assessment of Taal Lake. Philippine Council for Aquatic and Marine Resources Research and Development, Institute of Biological Sci ences UPLB, Los Banos, Laguna: 281 pp.

Zhou, S., X. Huang \& Q. Cai, 2009. Temporal and spatial distributions of rotifers in Xiangxi Bay of the Three Gorges Reservoir, China. International Review of Hydrobiology 94: 542559.

Zlotnicki, J., Y. Sasai, J. P. Toutain, E. U. Villacorte, A. Bernard, J. P. Sabit, J. M. Gordon, E. G. Corpuz, M. Harada \& J. T. Punongbayan, 2009. Combined electro magnetic, geochemical and thermal surveys of Taal Vol cano (Philippines) during the period 2005 2006. Bulletin of Volcanology 71: 2947. 